\title{
0 Mandado de injunção como possibilidade de efetivação dos Direitos Fundamentais Sociais
}

\author{
Camila Talheti Guellero ${ }^{1}$ \\ João Luiz Martins Esteves ${ }^{2}$
}

\begin{abstract}
Resumo
O mandado de injunção, concebido na Constituição Federal de 1988 para possibilitar o exercício dos direitos fundamentais constitucionalmente definidos, mas obstado pela falta de norma regulamentadora, pode ser vislumbrado como possibilidade de efetivação dos direitos fundamentais sociais, já que tais direitos carecem de um atuar positivo do Judiciário no sentido de promover a efetivação da cidadania social. Cabe ao Judiciário afastar-se do extremo apego ao princípio da separação de poderes, de sua postura de autorrestrição e dos óbices apresentados pela limitação orçamentária e trabalhar no sentido de promover a justiciabilidade dos direitos fundamentais sociais para que, assim, tais direitos possam ser efetivados na realidade social. Um dos caminhos para possibilitar que a efetivação dos direitos fundamentais sociais ocorra na sociedade brasileira é o Judiciário, especialmente na figura do Supremo Tribunal Federal, primar pelo bom manejo do mandado de injunção, possibilitando que este remédio constitucional realmente proporcione ao seu impetrante a fruição do direito até então obstaculizado pela omissão legiferante.
\end{abstract}

Palavras-Chave: Mandado de Injunção; Direitos Fundamentais Sociais.; Justiciabilidade; . Supremo Tribunal Federal.

\section{Introdução}

Desde que foi contemplado na Constituição de 1988, o mandado de injunção sempre abarcou em torno de si controvérsias a respeito de seu papel como instrumento de efetivação dos direitos constitucionais, principalmente no que tange à efetivação dos direitos fundamentais sociais.

Em razão de ter sido concebido para tutelar os direitos fundamentais constitucionalmente definidos, desde que obstados por falta de norma regulamentadora, 0 mandado de injunção não poderia deixar de tutelar também os direitos fundamentais

\footnotetext{
${ }^{1}$ Graduanda do 5o ano do curso de Direito da Universidade Estadual de Londrina.

${ }^{2}$ Mestre em Direito do Estado, Especialista em Filosofia Política, professor de direito constitucional da Universidade Estadual de Londrina, Procurador do Município de Londrina.
} 
sociais, já que estes integram os direitos fundamentais e retratam um dos fundamentos maiores da Carta de 1988, qual seja a cidadania.

Portanto, diante da expressiva dimensão que os direitos fundamentais sociais possuem na sociedade e no ordenamento jurídico nacional, este trabalho objetiva delinear o liame existente entre esse remédio constitucional e a cidadania, visando demonstrar como aquele pode ter papel de efetivar esta na realidade social.

Diante da relação intrínseca existente entre o mandado de injunção e os direitos fundamentais sociais, percebe-se a relevância em pretender desenvolver o estudo sobre a justiciabilidade dos direitos fundamentais sociais e a postura que o Poder Judiciário vem assumindo frente à sociedade que clama efetivação da cidadania, devendo ser despendida atenção especial à tentativa de analisar o mandado de injunção como possibilidade de efetivação dos direitos fundamentais sociais.

Para tanto, o presente tema encontra-se destrinchado em três partes principais. A primeira analisa a justiciabilidade dos direitos fundamentais sociais e algumas posições adotadas pelo Judiciário que podem estar colocando empecilhos ao seu papel de concretizador e efetivador da cidadania social.

Subsequentemente, a parte II dedica-se ao estudo do mandado de injunção, com ênfase ao seu conceito, objeto e efeitos conferidos pelo Supremo Tribunal Federal a suas decisões. Por fim, na terceira parte empreende-se uma análise jurisprudencial dos julgados do Supremo Tribunal Federal, com a finalidade de verificar como vem sendo manejado o mandado de injunção pela Corte Suprema e, se na prática, este instituto vem conseguindo manifestar seus efeitos no sentido de possibilitar a efetivação dos direitos fundamentais sociais.

\section{Justiciabilidade dos direitos fundamentais sociais}

Com o escopo de desenvolver o estudo sobre mandado de injunção como possibilidade de efetivação dos direitos fundamentais sociais, faz-se necessário empreender, antes de qualquer coisa, uma análise sobre a justiciabilidade destes direitos de segunda dimensão, ou seja, tentar verificar a possibilidade deles serem cobrados perante o Poder Judiciário quando não observados pelos Poderes Legislativo e Executivo 
A justiciabilidade dos direitos fundamentais sociais depara-se com várias barreiras que por vezes obstaculizam ao operador do direito dar efetividade aos direitos sociais e, consequentemente, sanar os graves problemas humanitários que assolam as sociedades contemporâneas (VANONI, 2008).

A limitação imposta à atuação do Judiciário, a limitação de recursos financeiros para arcar com as despesas do exercício dos direitos fundamentais sociais, as doutrinas que buscam o esvaziamento de tais direitos, e a própria postura muitas vezes autorrestritiva do Judiciário revelam-se como óbices à efetização dos direitos fundamentais sociais.

Vislumbra-se cabível ao tema em estudo verificar as características dos direitos fundamentais sociais que reforçam sua justiciabilidade, demonstrando, em contrapartida, algumas doutrinas que the são resistentes.

\section{Breves considerações sobre a teoria dos direitos fundamentais sociais}

É importante que seja apresentada a classificação dogmática dos direitos fundamentais, que, conforme os estudos de Sarlet (2008, p. 184-185), divide tais direitos em: direitos de defesa e direitos prestacionais.

Conforme leciona Sarlet, os direitos fundamentais, na condição de direitos de defesa:

[...] se dirigem a uma obrigação de abstenção por parte dos poderes públicos, implicando para estes um dever de respeito a determinados interesses individuais, por meio da omissão de ingerências ou pela intervenção na esfera de liberdade pessoal apenas em determinadas hipóteses e sob certas condições (SARLET, 2008, p. 186).

Pode-se reconhecer, assim, que os direitos de defesa podem ser identificados com os assim denominados direitos fundamentais de primeira dimensão, compreendidos pelos tradicionais direitos de liberdade e igualdade (SARLET, 2008, p. 187). Por sua vez, é importante ressaltar, com arrimo nos ensinamentos de Sarlet, que os direitos fundamentais sociais apesar de possuírem um conceito amplo que inclui tanto posições jurídicas tipicamente prestacionais como também diversa gama de direitos de defesa, podem ser enquadrados nesta última enquanto boa parte dos direitos dos trabalhadores, positivados nos artigos 70 a 11 da Constituição Federal, já que se revelam, neste aspecto, como "concretizações do direito de liberdade e do princípio da igualdade (ou da não- 
discriminação), ou mesmo posições jurídicas dirigidas a uma proteção contra ingerências por parte dos poderes públicos e entidades privadas" (2008, p. 192). Portanto, um exemplo típico deste caso é o direito de greve, disposto no artigo 9o da Lei Suprema.

Ainda no que concerne aos direitos de defesa, segundo a classificação de Sarlet, cumpre assinalar que o autor engloba neste rol os direitos políticos, uma vez que, embasado pelo critério da função predominante, entende que a dimensão prestacional dos mesmos, com exceção do elencado no artigo 17 , $§ 30$, da CF, assume caráter apenas indireto (2008, p. 197), prevalecendo, portanto, o caráter negativo próprio dos direitos de defesa.

Por outro lado, apresenta Sarlet (2008, p. 204), em sua classificação, a concepção de direitos prestacionais, os quais "implicam uma postura ativa do Estado, no sentido de que este se encontra obrigado a colocar à disposição dos indivíduos prestações de natureza jurídica e material (fática)". Na esteira deste entendimento, os direitos prestacionais podem incorporar tanto direitos sociais quanto direitos individuais. Como exemplos de direitos sociais prestacionais podem ser citados aqueles arrolados no artigo 60 da Constituição Federal, e como direitos individuais prestacionais podem ser reconhecidos a maior parte daqueles elencados no artigo 50 , do texto constitucional, que exigem do Estado a manutenção do aparelhamento administrativo, judicial e policial para sua efetividade e garantia (ESTEVES, 2007, p. 61).

Assim, diante destas breves explanações sobre os direitos fundamentais sociais, urge iniciar a análise sobre a justiciabilidade de tais direitos.

\section{A aplicabilidade imediata dos direitos fundamentais}

A tentativa de destituir as normas definidoras de direitos fundamentais sociais de sua aplicabilidade imediata pode ser reconhecida como obstáculo à justiciabilidade desses direitos.

0 texto constitucional, em seu artigo $50, \S 1$, dispõe que "as normas definidoras dos direitos e garantias fundamentais têm aplicação imediata". É bem verdade que a leitura rápida deste dispositivo constitucional poderia ensejar a sensação de ser este enunciado aplicado apenas aos direitos e garantias individuais descritos no artigo 50 da Carta Magna. Entretanto, o legislador constituinte, ao expressamente utilizar-se da expressão "direitos fundamentais", teve a intenção de estender os efeitos desta norma constitucional a todos os 
direitos fundamentais consagrados pela Constituição (VANONI, 2008), dentre os quais figuram os direitos sociais.

Assim, mesmo diante da existência de normas programáticas no texto

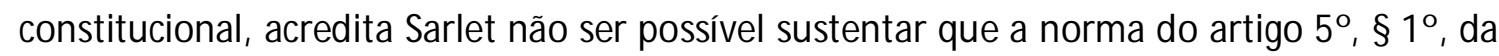
CF seja desnecessária ou supérflua (mesmo que não tenha o condão de outorgar às normas carentes de concretização sua plena eficácia) (SARLET, 2008, p. 284-285), já que, conforme observado em suas análises, todos os direitos fundamentais devem ser considerados como normas de aplicabilidade imediata, a saber: boa parte dos direitos fundamentais sociais, que por sua estrutura normativa e por sua função, enquadra-se nos direitos de defesa são considerados, sem maiores problemas, normas autoaplicáveis; por sua vez, os direitos sociais prestacionais se inserem na categoria das normas dependentes de concretização e efetivação legislativa, mas que, ainda assim, são dotadas de um mínimo de eficácia, porque geram efeitos jurídicos e servem de parâmetro de validade para normas infraconstitucionais.

Diante do posicionamento apresentado, reforça-se a ideia de que cumpre ao Judiciário a tarefa e o dever de possibilitar a efetivação dos direitos constitucionalmente concebidos, com especial atenção aos direitos fundamentais sociais, principalmente quando os outros dois poderes se restarem inertes ante a necessidade de cumprimento dos mandamentos constitucionais.

Contudo, mesmo detendo a responsabilidade da justiciabilidade dos direitos fundamentais sociais, o Judiciário quando se apega ao princípio da separação dos poderes e adota uma postura de autorrestriva, coloca empecilhos ao seu papel de concretizador e efetivador da cidadania social.

\section{0 princípio da separação dos poderes}

Impossível pretender analisar o princípio da separação dos poderes sem relembrar a teoria tripartida de M ontesquieu, que pretendeu elaborar:

[...] uma técnica que permitisse uma forma equilibrada e moderada de governo, e mais que isso, com poderes divididos (atribuição de atividades específicas funções - a órgãos distintos e autônomos), de tal modo que, no interior da estrutura do Estado, o poder se encarregasse de controlar ou limitar o próprio poder" (M ONTESQUIEU apud CLĖVE, 1993, p. 21). 
Contudo, atenta Clève que a "missão dos juristas, hoje, é a de adaptar a idéia de M ontesquieu à realidade constitucional de nosso tempo" (CLÈVE, 1993, p. 42), já que, com a incorporação nas Constituições Ocidentais do pós-guerra do modelo estatal social, a rígida separação entre os poderes passou a ser questionada.

Andreas J. Krell constata que o apego exagerado à teoria da separação dos poderes por grande parte dos juízes brasileiros nada mais é que resultado de uma postura conservadora da doutrina constitucional tradicional, que ainda não reinterpretou os velhos dogmas à luz das transformações sociais trazidas pelo Estado Social (2002, p. 91). Leciona o citado autor que é cada vez mais evidente que o princípio idealizado no século XVIII vem produzindo um "efeito paralisante" às reivindicações sociais, devendo, portanto, ser reinterpretado, já que somente assim poderá continuar servindo ao seu escopo de garantir os direitos fundamentais contra 0 arbítrio e, hoje também, a omissão estatal (KRELL, 2002, p. 88).

Nessa mesma linha de entendimento, reforça Esteves que o esquema formalista de separação de poderes nunca se revelou na prática, uma vez que sempre houve interpenetração de um poder no campo de atuação do outro, isto é, as três esferas sempre exerceram funções atípicas, administrativas, legislativas e judiciárias (ESTEVES, 2007, p. 7374). Portanto, conforme as lições de Flávia Piovesan, "o princípio da separação dos poderes deve, pois, ser compreendido à luz da sistemática de "freios e contrapesos", ou checks and balances, em que um órgão do Poder há de ser fiscalizado e controlado por um órgão de outro Poder" (PIOVESAN, 2003, p. 107-171).

Diante das considerações expostas, nota-se que a atuação do Judiciário na efetivação dos direitos fundamentais sociais não pretende substituir o Poder Legislativo e o Poder Executivo, mas sim trabalhar objetivamente com eles para a concretização deste objetivo. Não se pode negar que é preciso que o Judiciário atue de forma ativa, anulando regras inconstitucionais, dando aplicação à norma infraconstitucional no caso concreto de forma que o resultado seja adequado aos objetivos constitucionais e supra as omissões legislativas e administrativas, redefinindo políticas públicas quando ocorrer inoperância dos outros poderes (ESTEVES, 2007, p. 76).

0 que se deve ter em mente é que a regra elencada no artigo $2^{\circ}$ da Constituição de 1988, que define e garante a separação harmônica entre os poderes da República, deve ser 
utilizada como meio (e não fim) do Estado para atingir os seus objetivos fundamentais proclamados no artigo 30 da Lei Maior (ESTEVES, 2007, p. 80-81).

Vale arriscar dizer que se de um lado é vedado ao Judiciário assumir indiscriminadamente as funções típicas do legislador e do administrador, sob pena de real violação ao princípio da separação dos poderes, não é menos acertado entender que o órgão judiciário também não se pode manter alheio ao seu dever de efetivação dos preceitos constitucionais clamados pela sociedade, principalmente no que tange aos direitos fundamentais sociais.

\section{A autorrestrição do judiciário como empecilho à justiciabilidade dos direitos fundamentais sociais}

Outro obstáculo à justiciabilidade dos direitos fundamentais sociais pode ser identificado como a autorrestrição do Judiciário (ESTEVES, 2007, p. 82), pela qual os juízes consideram que a decisão das prioridades atinentes à cidadania não thes diz respeito, cabendo tal incumbência decisória apenas aos órgãos políticos do sistema.

Contudo, de acordo com as lições de Esteves (2007, p. 82-90), não parece existir no contexto pátrio oposição à legitimação do Judiciário na tarefa de dar efetividade à Constituição (ESTEVES, 2007, p. 86). Diante disso, parece ser plausível inferir que a existência de dificuldades na efetivação dos preceitos constitucionais pode estar partindo do próprio Poder Judiciário, em razão de sua postura autorrestritiva quando chamado a resolver os conflitos sociais e, principalmente efetivar os direitos fundamentais sociais reclamados pela sociedade brasileira (CAPPELLETTI, 1999, p. 90-91).

Essa posição de autorrestrição do Judiciário pode ter sido fruto da história constitucional brasileira (ESTEVES, 2007, p. 86-89), já que este órgão sempre se moldou ao poder estabelecido, negando a si próprio a tarefa política de intérprete e aplicador da Constituição.

Todavia, a partir do processo de democratização e promulgação da Constituição Federal de 1988 e do reconhecimento do conjunto ampliativo dos direitos sociais no Brasil, 0 papel do Judiciário de solucionador do apelo social e possibilitador da efetivação da cidadania passou a ganhar cada vez maior expressividade. Neste aspecto, muito bem observa Esteves que: 
[...] para efetivação desses direitos não são necessárias somente a declaração e a positivação daqueles, nem tão-somente a adoção de amplo e variado leque de opções processuais de controle da constitucionalidade. É preciso também que, vinculada a esse modelo, exista jurisdição construída sob a concepção de que efetivamente cabe ao Poder Judiciário, por meio do controle jurisdicional de constitucionalidade, a guarda da Constituição, pois aquele deve agir como órgão estatal vinculado aos seus comandos objetivos e não pode se esconder atrás de uma concepção doutrinária que leve à sua auto-restrição (ESTEVES, 2007, p. 89).

Com arrimo nas preciosas lições até aqui expostas, perceber-se que a plena justiciabilidade dos direitos fundamentais sociais pode ser alcançada na medida em que 0 Judiciário abandone as sombras das doutrinas formalistas, desapegando-se da absoluta separação dos poderes e da postura autorrestritiva que há tempos vem moldando suas decisões, e que passe a aceitar seu papel de concretizador e efetivador dos preceitos constitucionais, já que a própria sociedade o legitimou para solucionar os conflitos sociais e para efetivar os direitos fundamentais de $2^{\mathfrak{a}}$ dimensão, principalmente quando o Executivo e o Legislativo se mostram incapazes ou inoperantes para resolver tais questões.

\section{A limitação dos recursos públicos financeiros x mínimo existencial: a possibilidade de efetivação dos direitos fundamentais sociais}

Como não é possível desprezar o fato de que há limitação dos recursos públicos para realização das despesas com exercício dos direitos fundamentais e o fato de que esta limitação muitas vezes pode-se materializar numa barreira à justiciabilidade dos direitos fundamentais sociais (VANONI, 2008), faz-se por bem tentar desenvolver neste tópico uma análise sobre os limites dos recursos orçamentários e de que forma isso pode afetar a efetividade dos direitos fundamentais sociais.

A elaboração do orçamento deva respeitar e contemplar todas as diretrizes estabelecidas na Constituição, uma vez que, no Estado Social de Direito, questões ligadas ao cumprimento das tarefas sociais e a formulação das respectivas políticas não estão relegadas tão-somente ao governo e à administração pública, mas têm seu fundamento principal nas normas constitucionais sobre direitos sociais (KRELL, 2002, p. 100). Nesse momento torna-se oportuno repetir a indagação feita por Esteves em sua obra:

[...] se 0 orçamento e a definição de políticas públicas se encontram adequados aos comandos constitucionais, a quem cabe decidir definitivamente nas situações em 
que há de existir decisão sobre qual direito deve ser privilegiado e qual deverá aguardar sua vez quando não tem receita suficiente para arcar com toda a despesa necessária? (ESTEVES, 2007, p. 57).

Tal questionamento não é de simples solução, tornando-se imperioso atentar, primeiramente, para as diferentes características dos direitos fundamentais sociais, conforme a classificação de Sarlet apresentada no item 2.1 acima.

Segundo o mencionado anteriormente, percebe-se que os direitos sociais prestacionais estão profundamente ligados às tarefas exercidas pelo Estado na condição de Estado Social, ou seja, no papel de garantidor de uma adequada e justa distribuição dos bens existentes. Todavia, diante disso, pode surgir o argumento de que apenas os direitos de defesa poderiam ser exigidos judicialmente, em razão de não implicarem custos ao Estado, vez que os direitos a prestação, por exigirem dispêndio de verbas pelo Poder Público, não seriam justiciáveis vez que a destinação de verbas públicas depende de aprovação política (VANONI, 2008).

No entanto, antes de decidir qual direito tem privilégio de efetivação quando a receita orçamentária for insuficiente para atender as despesas públicas necessárias, deve ser observada a lição de Holmes e Sunstein, que, em síntese, defende que todos os direitos são positivos, na medida em que até mesmo os "direitos tradicionalmente definidos como negativos acarretam encargos econômicos e financeiros substanciosos para o poder público (um sistema eficiente de segurança pública e de administração judiciária, por exemplo)" (HOLM ES apud SARLET, 2008, p. 223-224). Sob esta óptica, pode-se verificar que os direitos de defesa também exigem atuação positiva do Estado e, portanto, geram necessidade de dispêndio de verbas públicas na sua realização. Assim, restaria fragilizado o argumento de que devem ser privilegiados os direitos de defesa (e mesmo os direitos individuais) em detrimento dos direitos prestacionais, levando a conclusão de que se os Poderes Legislativo, Executivo e mesmo o Judiciário dão prevalência à efetivação dos direitos fundamentais característicos de primeira dimensão, o fazem por escolha política, pois sabem que esses também estão sujeitos à escassez de recursos econômicos públicos como os direitos sociais prestacionais (HOLM ES apud SARLET, 2008).

Deste modo, percebe-se que uma postura ativa do Judiciário que afaste os argumentos de falta de verbas ou mesmo de falta da própria competência para decidir sobre 
a aplicação dos recursos públicos (SARLET, 2008, p. 342-343) e que, principalmente, pare de preterir a efetivação dos direitos sociais prestacionais para privilegiar a efetivação daqueles direitos de feição liberal, revela-se cada vez mais importante para possibilitar que a prestação dos serviços públicos atenda às necessidades sociais, e, assim, possibilite a efetivação dos direitos fundamentais sociais reclamados pela sociedade.

Para Barroso o Judiciário teria a responsabilidade de ordenar um "padrão mínimo" para o cumprimento destas tarefas estatais (BARROSO, 2003, p. 153-154). Torna-se necessário, deste modo, realizar o enquadramento dos direitos fundamentais sociais a um "mínimo existencial" para que seja possível sua efetivação pelo Poder Público.

Sobre esta temática, merece atenção a construção teórica desenvolvida por Ana Paula de Barcelos que apresenta entendimento muito pontual sobre quais devem ser os direitos prestados dentro do conceito de "mínimo existencial", merecendo ser destacado o seguinte trecho de suas lições:

Na linha do que se identificou no exame sistemático da própria Carta de 1988, o "mínimo existencial" que ora se concede é composto de quatro elementos, três materiais e um instrumental, a saber: a educação fundamental, a saúde básica, a assistência aos desamparados e 0 acesso à Justiça. Repita-se, ainda uma vez, que esses quatro pontos correspondem ao núcleo da dignidade da pessoa humana a que se reconhece eficácia jurídica positiva e, a fortiori, de direito subjetivo exigível diante do Poder Judiciário (BARCELOS apud ESTEVES, 2007, p. 65).

As considerações sobre o "mínimo existencial" também encontraram espaço nos estudos de Sarlet, defendendo este autor intrínseca correspondência entre o "mínimo existencial" e o princípio da dignidade humana, conforme pode ser observado no fragmento abaixo transcrito:

Assim, em todas as situações em que 0 argumento da reserva de competência do Legislativo (assim como 0 da separação dos poderes e as demais objeções aos direitos sociais na condição de direitos subjetivos a prestações) esbarrar no valor maior da vida e da dignidade da pessoa humana, ou nas hipóteses em que, da análise dos bens constitucionais colidentes (fundamentais, ou não) resultar a prevalência do direito social prestacional, poder-se-á sustentar, na esteira de Alexy e Canotilho, que, na esfera de um padrão mínimo existencial, haverá como reconhecer um direito subjetivo definitivo a prestações, admitindo-se, onde tal mínimo é ultrapassado, tão-somente um direito subjetivo prima facie, já que nesta seara - não há como resolver a problemática em termos de um tudo ou nada (SARLET, 2008, p. 372). 
Das lições apresentadas, portanto, pode-se inferir que embora a limitação dos recursos financeiros públicos possa constituir uma barreira fática à efetivação dos direitos fundamentais sociais, aqueles que estiverem presentes no "mínimo existencial", conforme a interpretação adotada no caso concreto, podem ser justiciáveis sob a forma de direitos subjetivos e, por conseguinte, teriam maior possibilidade de virem a ser efetivados na realidade social.

Assim, delimitada a análise sobre a justiciabilidade dos direitos fundamentais sociais e o papel de Judiciário como meio concretizador e efetivador destes direitos (obviamente sem qualquer pretensão de esgotar o tema), faz-se necessário voltar as direções deste trabalho ao mandado de injunção, com a intenção de desenvolver um estudo na tentativa verificar se este instituto constitucional introduzido no ordenamento jurídico pátrio pela Carta Magna de 1988 pode ser utilizado realmente como uma possibilidade de efetivação dos direitos fundamentais de segunda dimensão.

\section{0 mandado de injunção}

Conceito do instituto

0 instituto em estudo é um instrumento do controle de constitucionalidade difuso e encontra-se delineado na Constituição Federal de 1988, em seu artigo 5ํ, inciso LXXI. Por ser clara a disposição constitucional, o mandado de injunção pode ser conceituado como "garantia de exaltação constitucional, ação que visa conferir imediata aplicabilidade à norma constitucional nas hipóteses de normas fundamentais não autoaplicáveis ou de eficácia limitada" (ANASTÁCIO, 2003, p. 30).

$\mathrm{Na}$ mesma esteira de entendimento, acrescenta José Afonso da Silva que o mandado de injunção:

[...] constitui um remédio ou ação constitucional posto à disposição de quem se considere titular de qualquer daqueles direitos, liberdades ou prerrogativas inviáveis por falta de norma regulamentadora exigida ou suposta pela Constituição.

(SILVA, 2005, p. 448). 
Infere-se destas explanações que o mandado de injunção é uma garantia instrumental de direitos que não podem ser fruídos por ausência de norma regulamentadora verificada pela inércia legislativa (SIQUEIRA JÚNIOR, 2008, 364).

Abrangência protetiva do mandado de injunção

Neste momento, faz-se por bem tentar esclarecer: qual é a abrangência protetiva do instituto em tela? Quais são os direitos que o legislador constituinte pretendeu viabilizar ao implementar o mandado de injunção no texto constitucional de 1988? Sendo a injunção pátria concedida quando ausência de norma regulamentadora tornar inviável a fruição do exercício de direitos e liberdades constitucionais e das prerrogativas inerentes à nacionalidade, soberania e cidadania, estaria o objeto deste instituto limitado a esses direitos e liberdades expressamente previstos no artigo 5으, LXXI, CF?

Como resposta para tais indagações acabam por existir alguns entendimentos doutrinários divergentes quanto à extensão dos direitos e liberdades tutelados pela injunção, sendo, portanto, apropriado para o desenrolar deste estudo, tentar verificar quais seriam essas três correntes interpretativas: restritiva, intermediária e abrangente (MACHADO, 2004, p. 70).

Os defensores da primeira corrente reduzem significativamente o campo de incidência do writ ao sustentar que o mesmo alcança tão somente os direitos que possam ser deduzidos da condição de nacional e de cidadão, vez que a norma constitucional especificou o objeto da sua tutela expressamente. Este entendimento é desenvolvido por Manoel Gonçalves Ferreira Filho (2008, p. 325).

Por outro lado, aponta-se a corrente intermediária representada pelas ideias de Celso Ribeiro Bastos, segundo as quais mandado de injunção tutelaria somente os direitos contemplados no TíTULO II da Constituição (Direitos Individuais e Coletivos, Direitos Sociais, Direitos à Nacionalidade e Direitos Políticos) (BASTOS, 1998, p. 242).

Partindo-se para análise da corrente abrangente, verifica-se que esta visão doutrinária acredita que os direitos, liberdades e prerrogativas tuteláveis pela injunção são quaisquer direitos, liberdades e prerrogativas previstos em quaisquer dispositivos da Constituição, tendo em vista que inexiste qualquer restrição no art. 50, LXXI, do texto constitucional (PIOVESAN, 2003, p. 140). 
Diante do exposto, percebe-se que o mandado de injunção é cabível sempre que a falta de norma regulamentadora seja um obstáculo ao exercício dos direitos fundamentais definidos nas normas constitucionais que dependem de norma futura para que sejam efetivadas no plano da realidade social.

\section{Efeitos da decisão}

Para apresentar os efeitos da decisão proferida em sede de injunção, é inevitável socorrer-se da classificação utilizada por Lenza (2009, p. 740-741) em sua obra. De acordo com essa classificação, os efeitos do mandado de injunção podem ser divididos em duas posições iniciais, a não concretista e a concretistas; sendo que esta se subdivide em concretista geral e concretista individual; podendo ainda esta última posição ramificar-se em concretista individual direta e concretista individual intermediária.

A teoria não concretista se restringe a declarar a mora do órgão omisso, ou seja, do ente responsável pela elaboração da norma regulamentadora, não garantindo ao impetrante do mandado de injunção o exercício do direito pleiteado (PINTO, 2002, p. 58).

Importante ressaltar que, por muito tempo, a posição não concretista foi dominante no Supremo Tribunal Federal. Contudo, tal posicionamento sempre foi alvo das críticas da doutrina, uma vez que apenas declarar a mora legiferante não torna fruível o exercício dos direitos fundamentais obstados, restando a providência jurisdicional inócua, neste caso (LENZA, 2009, p. 741).

Contudo, hodiernamente, com a renovação dos membros da Excelsa Corte, as outras posições vêm ganhando força nos julgamentos dos mandados de injunção impetrados no STF, no sentido de se estar procurando conferir concretude aos direitos constitucionalmente previstos e carentes de regulamentação. Assim, passa-se à análise de tais teorias.

Pela concepção concretista, o Poder Judiciário deve declarar a omissão legislativa, além de conceder o direito fundamental pleiteado pelo impetrante até que sobrevenha norma integrativa pelo Legislativo (LENZA, 2009, p. 741). Essa linha concretista, conforme já mencionado, divide-se em concretista geral e concretista individual.

Na primeira posição, a decisão produz efeito erga omnes, o que, para alguns, equipara os efeitos do mandado de injunção aos da ADin por Omissão. Já na posição 
concretista individual, a decisão manifesta seus efeitos somente inter partes, vinculando apenas as partes da relação processual, servindo apenas ao caso concreto (PINTO, 2002, p. 58).

Por outro lado, a concepção concretista individual pode-se dividir em mais dois entendimentos distintos: a posição concretista individual direta e a concretista individual intermediária. A primeira acredita que, tão logo seja julgada procedente a ação, deve-se implementar a eficácia da norma constitucional, possibilitando o quanto antes o exercício do direito; já a segunda defende que, ao ser declarada a mora do Legislativo, deve the ser concedido um prazo para emissão da norma regulamentadora, mas que, sendo transcorrido in albis, deve o Poder Judiciário dar condições para que o impetrante possa finalmente exercer seu direito constitucional até então obstaculizado pela ausência de norma integradora (PINTO, 2002, p. 58).

Assim, após o estudo dos efeitos da decisão do mandado de injunção e com o desfecho do enfoque sobre algumas particularidades do instituto, parte-se para análise de alguns posicionamentos jurisprudenciais do Supremo Tribunal Federal na pretensão de verificar como vem sendo manejado o referido remédio constitucional pelo Tribunal Supremo, e se o posicionamento majoritário adotado por esta corte quanto à decisão em sede de injunção vem possibilitando (ou pode vir a possibilitar) a concretização e efetivação dos direitos fundamentais sociais por meio desta via.

\section{Mandado de injunção na efetivação dos direitos fundamentais sociais e a interpretação jurisprudencial do supremo tribunal federal}

\section{M andado de injunção e o enfoque não concretista da decisão do mi 107/ df}

O MI 107/DF foi o primeiro mandado de injunção a ser exaustivamente analisado pelo STF, tendo sido o teor de sua decisão seguido por outros julgados desde a data de seu julgamento em dois de agosto de 1991. Nesse caso o impetrante pleiteava que fosse suprida a ausência da norma integradora a que se refere 0 artigo 42, § 90 da Constituição Federal, possibilitando, assim, o exercício do direito de estabilidade do servidor público militar.

A decisão proferida no MI 107/DF possibilitou uma apreciação mais uniforme do instituto da injunção pela Suprema Corte e também pelos demais Tribunais, visto que foi 
fixado entendimento reconhecendo a eficácia plena e auto-aplicabilidade do mandado de injunção. Além disso, determinou que em relação ao procedimento esse remédio constitucional deve utilizar no que couber, o do mandado de segurança (PINTO, 2002, p. 52).

Convém ressaltar ainda que foi aplicada a posição não concretista ao fixar os efeitos da decisão, já que os Ministros, majoritariamente, decidiram por conceder natureza mandamental ao mandado de injunção, já que, naquela época, o objetivo deste instituto constitucional era tão-somente obter do Judiciário a declaração de inconstitucionalidade do órgão responsável pela edição de norma regulamentadora faltante, bem como dar-lhe ciência da omissão para que adotasse as devidas providências (PINTO, 2002, p. 52).

Assim, nota-se que o MI 107/DF é um exemplo típico do posicionamento que por muito tempo foi adotado pelo Supremo Tribunal Federal, onde a decisão não conferia ao impetrante o efetivo exercício do direito pleiteado, vez que apenas tinha a condão de comunicar a omissão ao órgão legiferante.

Deste modo, percebe-se que a prestação jurisdicional, nesse e em outros casos semelhantes, restou-se inócua, já que o judiciário cerceou seu papel de efetivador dos direitos constitucionais ao valer-se de uma postura tímida e autorrestritiva baseada no respeito cego ao princípio da separação dos poderes. Assim, em razão da finalidade não concretista conferida ao MI 107/DF, no presente caso não foi possível verificar que 0 mandado de injunção atuou como meio possibilitador a conferir efetivação aos direitos fundamentais, muito menos aos de cunho social.

\section{M andado de Injunção e o direito de greve dos servidores públicos}

O mandado de injunção no 670/ES impetrado pelo Sindicato dos Servidores Policiais Civis do Espírito Santo - SINDIPOL, ao lado do mandado de injunção 708/DF impetrado pelo Sindicato dos Trabalhadores em Educação do Município de João Pessoa - SINTEM, e do mandado de injunção no 712/PA impetrado pelo Sindicato dos Trabalhadores do Poder Judiciário do Estado do Pará - SINJ EP pretendia que fosse garantido aos seus associados o exercício do direito de greve previsto no artigo 37, VII, da CF.

Em 25 de outubro de 2007, o Supremo Tribunal Federal concluiu o julgamento das três ações constitucionais. Por unanimidade, foi declarada a omissão legislativa e, conforme a posição majoritária adotada pelos Ministros, decidiu-se também em "determinar a 
aplicação das Leis no 7.701/1988 e 7.783/1989 aos conflitos e às ações judiciais que envolvam a interpretação do direito de greve dos servidores públicos civis" (MI 670/ES, 2007, p. 51).

Nota-se, então, que nestes três julgados o entendimento majoritário dos membros do STF foi no sentido de conceder efeito erga omnes às decisões, na medida em que propôs, para solução da omissão legislativa, no que couber, a aplicação das leis que dispõem sobre o exercício do direito de greve no setor privado, sem, todavia, restringir esta aplicação apenas ao caso concreto, estendendo o efeito a todas as ações judiciais que discutam a interpretação do direito de greve do funcionalismo público.

Portanto, seguindo as orientações da classificação estudada no último item do capítulo passado, pode-se dizer que no caso dos mandados de injunção aqui analisados, o Supremo Tribunal Federal, majoritariamente, optou por utilizar-se da teoria concretista geral (LENZA, 2009, p. 742).

Percebe-se que 0 entendimento prolatado nestes julgados apresentou-se muito diferente da interpretação até então dada pelo STF em relação aos efeitos do mandado de injunção, já que este tribunal costumava valer-se de uma postura não-concretista, conforme já analisado, limitando-se a "constatar a inconstitucionalidade da omissão e a determinar que o legislador empreendesse as providências requeridas" (MI670/ES, 2007, p. 19).

Entretanto, no caso do direito de greve dos servidores públicos civis, a Corte Suprema ao conferir ao mandado de injunção efeito erga omnes teria confundido-o com a ação de inconstitucionalidade por omissão, sendo importante destacar as lições de Volney Zamenhof de Oliveira Silva sobre o assunto:

[...] a amplitude dos efeitos de uma declaração de inconstitucionalidade por omissão é genérica e abstrata, enquanto que em relação ao mandado de injunção, a decisão é individual, o que implica dizer que para cada caso concreto, o órgão julgador tem que emanar norma regulamentadora (SILVA, 1993, p. 62).

Além disso, merece ser ressaltado o posicionamento do Ministro Joaquim Barbosa que se mostrou contrário a concessão do efeito erga omnes aos mandados de injunção ora analisados. Nesse sentido, manifestou-se o voto do M inistro: 
Tenho reservas sobre a natureza objetiva que se quer conferir ao mandado de injunção. Nesse sentido, ponho-me de acordo com as restrições manifestadas pelos Ministros Ricardo Lewandowski e Carmen Lúcia, por exemplo. Mas não se pode negar que os efeitos se repetirão. Nos termos em que se forma a maioria, 0 resultado prático de negar-se o efeito erga omnes é que a Corte repetirá o julgamento, apenas para afirmar em diversas oportunidades o mesmo que afirmou nessas últimas sessões. Mas, por outro lado, essa constatação prática não me parece suficiente para alterar a natureza do mandado de injunção, que é via vinculada ao interesse. Talvez fosse 0 caso, para resolver uma parte desse problema de repetição de feitos, já que não há dúvidas sobre a omissão legislativa, de editar-se uma súmula vinculante sobre a matéria (MI 670/ES, 2007, p. 183).

Assim, analisando as jurisprudências acima, percebe-se que, mesmo sendo o direito de greve um direito de defesa, que, conforme classificação de Sarlet exige apenas uma abstenção do Estado para com o indivíduo, importante é reconhecer que nos casos em tela os direitos fundamentais sociais reclamados foram efetivados na realidade social mediante a utilização do mandado de injunção que, graças à posição concretista geral conferida pelos M inistros da Corte Suprema à decisão, seus efeitos puderam ser desfrutados tanto no caso concreto como por terceiros às relações processuais ora elencadas.

\section{Mandado de Injunção e o direito à aposentadoria especial por atividade insalubre}

Por sua vez, o mandado de injunção 721/DF, ao lado do MI 788/DF e do MI 795/DF, pleiteou que fosse suprida a falta de norma regulamentadora a que se refere 0 artigo 40, $\S$ 4ํ da Constituição Federal, a fim de viabilizar o exercício do direito à aposentadoria especial por atividade insalubre. 0 primeiro foi julgado em 30 de agosto de 2008, tendo sido sua decisão seguida nos outros dois, os quais foram julgados em 15 de abril de 2009.

No caso do MI 721/DF, o voto do relator, Ministro Marco Aurélio, asseverou que cabe ao Judiciário não apenas declarar a omissão ao poder incumbido de regulamentar a norma faltante, mas sim viabilizar ao impetrante, no caso concreto, o exercício do direito até então obstaculizado pela inércia legiferante (MI 721/DF, 2008, p. 9-10).

Por unanimidade, neste julgado, o Pleno do STF acompanhou o voto do ministrorelator para "estabelecer para o caso concreto e de forma temporária, até a vinda da lei complementar prevista, as balizas do exercício dos direitos assegurados constitucionalmente" (MI 721/DF, 2008, p. 8), ou seja, foi deferido ao impetrante o direito à 
aposentadoria, nos termos do artigo 57 da Lei no 8.213/1991, que dispõe sobre o plano de benefícios da Previdência Social (LENZA, 2009, 742).

Nota-se que, tanto no julgamento do MI 721/DF, como nos outros dois que 0 sucederam, foi adotada a posição concretista individual direta, visto que Judiciário posicionou-se no sentido de efetivar, no caso concreto e imediatamente, o direito fundamental social reclamado pelo impetrante.

Assim, o Supremo, em sua atual composição e mediante o bom manejo do remédio constitucional estudado, vem conferindo ao mandado de injunção a possibilidade de colaborar com a efetivação das normas constitucionais carentes de regulamentação, especialmente daquelas que dispõe sobre os direitos fundamentais sociais, já que estes, por carecerem de um agir positivo do Judiciário, não podem deixar que a omissão legislativa obstaculize sua efetivação no mundo real.

\section{Conclusão}

Verificado que o mandado de injunção foi concebido na Carta M agna de 1988 para possibilitar o exercício dos direitos fundamentais constitucionalmente definidos, mas que se encontravam obstaculizados em razão de falta de norma regulamentadora, é inegável observar que este instrumento constitucional não poderia deixar de tutelar também os direitos fundamentais sociais. Tal liame se estabelece em virtude da abrangência protetiva do mandado de injunção abarcar todos os direitos fundamentais elencados no texto constitucional (e não apenas os descritos no inciso LXXI, do artigo 5ํ, da CF), já que a intenção do legislador originário na dicção deste enunciado constitucional não foi restringir o objeto do instituto, mas apenas exemplificar algumas possibilidades.

Assim, a partir da constatação da intrínseca relação entre o mandado de injunção e os direitos fundamentais sociais, passou a ser traçada uma análise com o intuito de verificar se esta ação constitucional seria uma possibilidade de efetivação dos direitos fundamentais sociais infruíveis em virtude da omissão legiferante.

Deste modo, iniciou-se o presente trabalho com o estudo sobre a justiciabilidade dos direitos fundamentais sociais e a postura que o Poder Judiciário vem assumindo frente ao anseio social que clama efetivação dos direitos sociais. 
Quando do estudo da justiciabilidade dos direitos fundamentais sociais, foi desenvolvida uma breve análise sobre tais direitos, com base na classificação de Sarlet que os divide em direitos de defesa e direitos prestacionais. Importante ressaltar que a definição desses termos teve suma relevância para o desenvolvimento do tema proposto, já que foi a partir dela que pôde ser percebido que os direitos fundamentais sociais possuem maneiras diferentes de justiciabilidade, em razão das próprias peculiaridades da natureza de cada um, a saber: os direitos de defesa exigem uma abstenção do Estado e os direitos prestacionais requerem uma atuação positiva do mesmo para que possam ser justiciáveis e efetivados.

Foi apontado também que as normas constitucionais que instituem tais direitos merecem ter reconhecida sua aplicabilidade imediata, por mais ínfima que esta possa parecer, já que, principalmente no caso dos direitos prestacionais, esta aplicabilidade somente ganha efetividade com a intervenção de comandos integrativos.

Percebeu o expressivo papel que o Judiciário deve desempenhar na concretização e efetivação dos direitos fundamentais sociais, já que cabe a este órgão agir ativamente no sentido de conferir aplicabilidade às normas instituidoras de direitos fundamentais sociais, possibilitando a efetivação destes ao suprir as omissões legislativas que os obstavam. Deste modo, detendo a responsabilidade da justiciabilidade dos direitos fundamentais sociais, o Judiciário não deve se apegar cegamente ao princípio da separação dos poderes nem adotar uma postura autorrestriva, já que isso configura, conforme o exposto, empecilhos gravíssimos ao seu papel de efetivador da cidadania social.

Além disso, foi analisado também que cabe ao Judiciário não permitir que a limitação dos recursos financeiros públicos constitua uma barreira fática à efetivação dos direitos fundamentais sociais, devendo este órgão enquadrá-los no "mínimo existencial" para que possam ser justiciáveis sob a forma de direitos subjetivos e, consequentemente, garantir maior possibilidade de virem a ser efetivados na realidade social.

Vale lembrar que a ideia de "mínimo existencial" compreendeu varias interpretações conforme a linha de pensamento adotada por cada autor, entretanto, parece que a posição defendida Sarlet possui maior apelo frente aos posicionamentos jurisprudenciais do STF, vez que, conforme o observado com a análise dos julgados, parece que este tribunal vem priorizando zelar pelos direitos fundamentais sociais intimamente ligados ao princípio da dignidade da pessoa humana, já que é somente através de prestações 
que atendam às necessidades sociais e melhorem a condição de vida humana que os direitos sociais passam a ser efetivados na meio social.

Assim, o Supremo, em sua atual composição, conferiu efetividade ao mandado de injunção ao afastar-se da teoria não concretista, priorizando as teorias concretistas geral e/ou individual ao proferir as decisões. Ao agir desta maneira, o STF não está ferindo o princípio da separação de poderes, já que, conforme os dizeres de Piovesan, através do bom manejo do mandado de injunção o Judiciário está tornando viável o exercício de direitos e liberdades constitucionais no caso concreto, assumindo, assim, "embora em dimensões mais alargadas, sua função típica e própria, qual seja a função jurisdicional, respondendo satisfatoriamente ao caso concreto" (2003, p. 169).

\section{Referências}

ANASTÁCIO, Rachel Bruno. Mandado de injunção: em busca da efetividade da Constituição. Rio de Janeiro: Lumen Juris, 2003.

BARROSO, Luís Roberto. 0 direito constitucional e a efetividade de suas normas. 7. ed. Rio de Janeiro: Renovar, 2003.

BASTOS, Celso Ribeiro. Curso de direito constitucional. São Paulo: Saraiva, 1998.

CAPPELLETTI, M auro. Juízes legisladores? Porto Alegre: Sergio Antonio Fabris, 1999.

CLĖVE, Clèmerson M erlin. Atividade legislativa do Poder Executivo no Estado contemporâneo e na Constituição de 1988. São Paulo: Revista dos Tribunais, 1993.

ESTEVES, João Luiz Martins. Direitos fundamentais sociais no Supremo Tribunal Federal. São Paulo: Método, 2007.

FERREIRA FILHO, Manoel Gonçalves. Curso de direito constitucional. São Paulo: Saraiva, 2008.

KRELL, Andreas ]. Direitos sociais e controle judicial no Brasil e na Alemanha: os (des)caminhos de um direito constitucional "comparado". Porto Alegre: Sergio Antonio Fabris, 2002.

LENZA, Pedro. Direito constitucional esquematizado. São Paulo: Saraiva, 2009.

M ACHADO, Carlos Augusto Alcântara. Mandado de injunção: um instrumento de efetividade da constituição. São Paulo: Atlas, 2004. 
M ANDADO de Injunção - MI 107/DF. Disponível em: «ttp://www.stf.jus.br/portal/jurisprudencia/listar] urisprudencia.asp?s1=mandado +de+inju n\%E7\%E30 +107\&pagina=2\&base=baseAcordaos>. Acesso em: 13 jun. 2009.

M ANDADO de Injunção - MI 670/ES. Disponível em:

বhttp://www.stf.jus.br/portal/jurisprudencia/listar]urisprudencia.asp?s1=mandado \%20de\% 20injunção\%20670\&base=baseAcordaos>. Acesso em: 13 jun. 2009.

M ANDADO de Injunção - MI 721/DF. Disponível em:

বhttp://www.stf.jus.br/portal/jurisprudencia/listarJurisprudencia.asp?s1=mandado $\% 20$ de\% 20injunção\%20721\&base=baseAcordaos>. Acesso em: 13 jun. 2009.

PINTO, Tácito L. M aranhão. 0 mandado de injunção: trajetória de um Instituto. São Paulo: LTR, 2002.

PIOVESAN, Flávia. Proteção judicial contra omissões legislativas: ação direta de inconstitucionalidade por omissão e mandado de injunção. São Paulo: Revista dos Tribunais, 2003.

SARLET, Ingo Wolfgang. A eficácia dos direitos fundamentais sociais. Porto Alegre: Livraria do Advogado, 2008.

SILVA, José Afonso da. Curso de direito constitucional positivo. São Paulo: Malheiros, 2005.

SILVA, Volney Zamenhof de Oliveira. Lineamentos do mandado de injunção. São Paulo: Revista dos Tribunais, 1993.

SIQUEIRA JÚNIOR, Paulo Hamilton. Direito processual constitucional: de acordo com a reforma do judiciário. São Paulo: Saraiva, 2008.

VANONI, Daniel Bofill. Os direitos sociais na Constituição Federal de 1988: em busca de um modelo dogmático de tutela judicial dos direitos fundamentais de segunda dimensão. Jus Navigandi, Teresina, v. 12, n. 1793, 29 maio 2008. Disponível em:

বhttp://jus2.uol.com.br/doutrina/texto.asp?id=11318>. Acesso em: 7 ago. 2009. 